\title{
CONTRIBUTION OF LEU AND HYP RESIDUES TO ANTIOXIDANT AND ACE-INHIBITORY ACTIVITIES OF PEPTIDE SEQUENCES ISOLATED FROM SQUID GELATIN HYDROLYSATE
}

\author{
Alemán, A., Giménez, B., Pérez, E., Gómez-Guillén, M.C. and Montero, P.* \\ Instituto del Frío-ICTAN (CSIC)**, Ciudad Universitaria, 28040 Madrid, Spain
}

* Corresponding author: P. Montero (mpmontero@if.csic.es)

** This centre has implemented and maintains a Quality Management System which fulfils the requirements of the ISO standard 9001:2000

\begin{abstract}
Squid gelatin obtained from inner and outer tunics was hydrolyzed with Alcalase to isolate antioxidant peptide sequences. The ACE-inhibitory activity of the isolated peptides was also evaluated. After fractionation by ultrafiltration and size-exclusion chromatography into four fractions, the antioxidant activity of the peptide fractions was determined by radical scavenging ability and ferric reducing power. Fraction FIII showed the highest antioxidant activity, although slight differences could be expected in the antioxidant activity of the different fractions based on the amino acid composition. FIII was subjected to liquid chromatography and tandem mass spectrometry (LCMS/MS) and two major compounds were identified: the compound with $\mathrm{m} / \mathrm{z} 952.42$, which could be mostly comprised by the carbohydrate fucose, and the peptide with $\mathrm{m} / \mathrm{z}$ 1410.63. Three possible sequences were proposed for this peptide, and the contribution of Leu or Hyp residues to the antioxidant and ACE-inhibitory activities of the resulting sequence was evaluated. The presence of Leu residues in the peptide sequence in
\end{abstract}


replacement of Hyp seems to play an important role in the antioxidant and ACEinhibitory activity.

Key words: squid gelatin, antioxidant peptides, ACE-inhibitory peptides, mass spectrometry 


\section{Introduction}

Giant squid (Dosidicus gigas) is widely distributed in the Pacific Ocean, and is especially abundant near the coasts of Peru and Mexico. The big size of the mantle together with the fact that it is usually marketed as cleaned and peeled mantle, imply the generation of important amounts of collagenous residues (inner and outer tunics), which could yield high value-added products. Squid skin gelatins have been reported to give biologically active peptides with high antioxidant activity, due to their radical scavenging activities, chelating effects on metal ions, reducing power or lipid peroxidation (Mendis, Rajapakse, Byun \& Kim, 2005a; Rajapakse, Mendis, Byun \& Kim, 2005; Lin \& Li, 2006; Giménez, Alemán, Montero \& Gómez-Guillén, 2009). However, to the best of our knowledge, ACE-inhibitory capacity has not been described in squid skin gelatin hydrolysates, although this activity has been reported in collagen and gelatin hydrolysates from other marine species (Kim, Byun, Park \& Shahidi, 2001; Fahmi, Morimura, Guo, Shigematsu, Kida \& Uemura, 2004; Kim \& Mendis, 2006; Zhao, Li, Liu, Dong, Zhao \& Zen, 2007).

Lipid oxidation leads to the loose of food quality and shortening of shelf-life, as well as the production of potentially toxic reaction products. Furthermore, oxidative damage is related to numerous health disorders such as diabetes, cancer, neurodegenerative and inflammatory diseases (Pryor, 1982; Butterfield, Castenga, Pocernich, Drake, Scapagnini \& Calabrese, 2002).

Hypertension is a worldwide problem of epidemic proportions that affects $15-20 \%$ of all adults. Angiotensin-I converting enzyme (ACE) plays an important role in the regulation of blood pressure and hypertension because catalyzes the conversion of inactive angiotensin-I into angiotensin-II, a potent vasoconstrictor (Goodfriend, Elliott \& Catt, 1996) and inactivates bradykinin, a potent vasodilator (Witherow, Helmy, 
Webb, Fox \& Newby, 2001). Synthetic inhibitors of ACE are often used to treat hypertension (Pahor, Psaty, Alderman, Applegate, Williamson \& Furberg, 2000) and other cardio-related diseases. However, these compounds can cause adverse side effects (Atkinson \& Robertson, 1979) and, therefore, interest for natural inhibitor has increased.

Biological activities of protein hydrolysates are related to the amino acid composition and sequence, size and configuration of peptides. For example, the presence of certain amino acids, such as His, Trp, Tyr, Phe, Met, Leu, Gly or Pro has been reported to enhance the scavenging activities of peptides (Chen, Muramoto, Yamauchi \& Nokihara, 1996; Park, Jung, Nam, Shahidi \& Kim, 2001; Hernández-Ledesma, Dávalos, Bartolomé \& Amigo, 2005; Mendis, Rajapakse \& Kim, 2005b; Li, Chen, Wang, Ji \& Wu, 2007). Regarding the ACE-inhibitory activity, binding to ACE is strongly influenced by the C-terminal tripeptide sequence. Although the structure-activity relationship of food derived ACE inhibitory peptides has not yet been fully established, ACE prefers inhibitors containing hydrophobic amino acid residues at each of the three C-terminal positions (Murray \& FitzGerald, 2007).

The objective of this study was the isolation and identification of peptides sequences with antioxidant activity from an enzymatic hydrolysate of squid gelatin. Furthermore, the ACE-inhibitory activity of the isolated peptides was evaluated, as well as the contribution of Leu and Hyp residues to both biological activities.

\section{Materials and methods}

\subsection{Gelatin hydrolysate}

Frozen inner and outer tunics of jumbo flying squid (Dosidicus gigas) were kindly provided by PSK Océanos, S.A. (Vigo, Spain). Gelatin was extracted using the method 
described by Giménez et al., 2009. Dry gelatin (2.5\% w/v) was dissolved in MiliQ water and subjected to enzymatic hydrolysis using Alcalase ${ }^{\circledR}$ (EC 3.4.21.14, 2.4L, 2.64 AU/g, Sigma-Aldrich, Inc., St. Louis, Mo., USA) with an enzyme-substrate ratio of 1:20 (w:w) in optimal conditions for enzymatic activity $\left(\mathrm{pH} 8,50^{\circ} \mathrm{C}\right)$ for $3 \mathrm{~h}$. The $\mathrm{pH}$ of the reaction was kept constant by addition of $1 \mathrm{~N} \mathrm{NaOH}$ solution to the reaction medium using a pH-stat (TIM 856, Radiometer Analytical, Villeurbanne Cedex, France). The enzyme was inactivated by heating at $90^{\circ} \mathrm{C}$ for $10 \mathrm{~min}$ and the gelatin hydrolysate was the supernatant after centrifugation at $3000 \mathrm{~g}$ for $15 \mathrm{~min}$.

The degree of hydrolysis (DH), calculated according to Adler-Nissen (1977), was $30.52 \%$.

\subsection{Fractionation of the hydrolysate}

\section{Ultrafiltration}

The gelatin hydrolysate was fractionated by ultrafiltration with a molecular weight cutoff (MWCO) membrane of $10 \mathrm{kDa}$ (Omega $10 \mathrm{kD}$ Centramate $^{\mathrm{TM}}$ cassette medium screen channel, Pall Corporation, Madrid, Spain). The hydrolysate permeate fraction was freeze-dried and designed as UF-10.

\section{Size-exclusion chromatography (SEC)}

The UF-10 was dissolved in MiliQ water at $10 \mathrm{mg} / \mathrm{mL}$ and loaded onto a gel filtration column (HiLoad ${ }^{\mathrm{TM}}$ 26/60 Superdex 30 pg, GE Healthcare, Barcelona, Spain), with a fractionation range below $10000 \mathrm{Da}$. The injection volume was $2 \mathrm{~mL}$ and the flow rate $0.5 \mathrm{~mL} / \mathrm{min}$ using MiliQ water as mobile phase. Peptides monitored at $215 \mathrm{~nm}$ were collected, freeze-dried and stored at $-80^{\circ} \mathrm{C}$ for further assay. Vitamin B12 (1355 Da, Sigma Aldrich, Madrid, Spain) and 6.7-dimethoxy-2-(4-methyl-1.4-diazepan-1-yl) 
quinazolin-4-amine (317 Da, from Lera's group, University of Vigo, Spain) were used as molecular weight standard.

\subsection{Amino acid composition}

The different fractions isolated by SEC were dissolved at $1 \mathrm{mg} / \mathrm{mL}$ in MiliQ water. An amount of $50 \mu \mathrm{L}$ of sample were dried and hydrolysed in vacuum-sealed glass tubes at $110^{\circ} \mathrm{C}$ for $24 \mathrm{~h}$ in the presence of continuously boiling $6 \mathrm{~N} \mathrm{HCl}$ containing $0.1 \%$ phenol with norleucine (Sigma-Aldrich, Inc., St. Louis, MO, USA) as internal standard. After hydrolysis, samples were again vacuum-dried, dissolved in application buffer, and injected onto a Biochrom 20 amino acid analyser (Pharmacia, Barcelona, Spain).

\subsection{Antioxidant activities}

FRAP assay

FRAP (Ferric Reducing Ability of Plasma) is a measure of the reducing power of samples and was performed according to the method described by Benzie and Strain (1996) with some modification. An amount of $60 \mu \mathrm{L}$ of dissolved sample (UF-10, peptide fractions, synthetic peptides) was incubated $\left(37^{\circ} \mathrm{C}\right)$ with $60 \mu \mathrm{L}$ of MiliQ water and $900 \mu \mathrm{L}$ of FRAP reagent containing $10 \mathrm{mM}$ of TPTZ (2,4,6-tripyridyl-s-triazine) and $20 \mathrm{mM}$ of $\mathrm{FeCl}_{3}$. Absorbance values were read at $595 \mathrm{~nm}$ after $30 \mathrm{~min}$. Results were expressed as $\mu \mathrm{mol} \mathrm{Fe}^{2+}$ equivalents/g of protein, based on a standard curve of $\mathrm{FeSO}_{4} \cdot 7 \mathrm{H}_{2} \mathrm{O}$. All determinations were performed at least in triplicate.

ABTS assay

The ABTS radical [2,2'-azino-bis-(3-ethylbenzothiazoline-6-sulfonic acid) ] scavenging capacity was carried out according to the method of Re, Pellegrini, Proteggente, 
Pannala, Yang, and Rice-Evans (1999). The stock solution of ABTS radical consisted of $7 \mathrm{mM}$ ABTS in potassium persulphate $2.45 \mathrm{mM}$, kept in the dark at room temperature for $16 \mathrm{~h}$. An aliquot of stock solution was diluted with MiliQ water in order to prepare the working solution of ABTS radical with absorbance at $734 \mathrm{~nm}$ of $0.70 \pm 0.02$. A 20 $\mu \mathrm{L}$ aliquot of sample (UF-10, peptide fractions, synthetic peptides) was mixed with $980 \mu \mathrm{L}$ of ABTS reagent. The mixture was then left to stand in the dark at $30^{\circ} \mathrm{C}$ for $10 \mathrm{~min}$ and absorbance values were read at $734 \mathrm{~nm}$. Results were expressed as $\mathrm{mg}$ Vitamin C Equivalent Antioxidant Capacity (VCEAC)/g of protein, based on a standard curve of vitamin C. All determinations were performed at least in triplicate.

\subsection{Purification of the antioxidative peptides}

The fraction with the highest antioxidant activity was analyzed on-line by LC-ESI-ITMS/MS using a LC system model Surveyor (Thermo-Finnigan, San Jose, CA, USA) coupled with a linear IT mass spectrometer model LTQ (Thermo-Finnigan). Peptides were concentrated onto a RP trap column (PepMap C18 $\mu$-precolumn $300 \mathrm{~mm}$ id x 1 $\mathrm{mm}$; Dionex, Amsterdam, The Netherlands) for $5 \mathrm{~min}$ and eluted online onto a $75 \mu \mathrm{m} \mathrm{x}$ $100 \mathrm{~mm}$ Biobasic-C18 RP analytical column (PicoFrit column, New Objective, Ringoes, NJ, USA) at a flow rate of $200 \mathrm{~nL} / \mathrm{min}$. Water containing $0.1 \%$ of formic acid and acetonitrile containing $0.1 \%$ of formic acid, were used as solvents $\mathrm{A}$ and $\mathrm{B}$, respectively, using the following gradient: $5 \% \mathrm{~B}$ for $5 \mathrm{~min}, 5-70 \% \mathrm{~B}$ in $60 \mathrm{~min}$, and 95\% B for $10 \mathrm{~min}$. The mass spectrometer was operated in the data-dependent mode to automatically switch between full MS and MS/MS acquisition. The parameters for ion scanning were the following: Full-scan MS (400-1800 m/z) plus top twelve peaks Zoom and MS/MS scans (isolation width $2 \mathrm{~m} / \mathrm{z}$ ), normalized collision energy 35\%. The scanning was performed using a dynamic exclusion list (20s exclusion list size of 50). 
De novo peptide sequencing of the major peaks was performed by manual interpretation of the ion series in the spectra. BLAST program was used for homology searches between manual obtained sequences and those in the NCBInr database.

\section{MALDI-TOF MS Analysis}

The fraction with the highest antioxidant activity was also analyzed by MALDI-TOF MS. $1 \mu \mathrm{L}$ was spotted onto a MALDI target plate and allowed to air-dry at room temperature. Then, $0.4 \mu \mathrm{L}$ of a $3 \mathrm{mg} / \mathrm{ml}$ of $\alpha$-cyano-4-hydroxy-transcinnamic acid matrix (Sigma) in 50\% acetonitrile were added to the dried peptide digest spots and allowed again to air-dry at room temperature. MALDI-TOF MS analyses were performed in a 4800 Proteomics Analyzer MALDI-TOF/TOF mass spectrometer (Applied Biosystems, Framingham, MA) operated in positive reflector mode, with an accelerating voltage of $20000 \mathrm{~V}$.

\subsection{Peptide syntheses}

Peptides were synthesized by Fmoc solid-phase using an Applied Biosystems Model 432A Synergy peptide synthesizer. The purity of the peptides was verified by analytical mass spectrometer system (Thermo Mod. Finnigan ${ }^{\mathrm{TM}} \mathrm{LXQ}^{\mathrm{TM}}$ ) coupled to a Surveyor HPLC.

\subsection{ACE inhibition}

The reversed-phase high performance liquid chromatography (RP-HPLC) was used to determine the ACE inhibition capacity of the synthetic peptides. The method was according to $\mathrm{Wu}$, Aluko and Muir (2002) with some modifications. The total reaction volume was $225 \mu \mathrm{L}$, made up of $50 \mu \mathrm{L}$ of $5 \mathrm{mM}$ HHL, $160 \mu \mathrm{L}$ of $0.025 \mathrm{U} / \mathrm{mL}$ of ACE 
and $20 \mu \mathrm{L}$ of sample at different concentration (all prepared with $100 \mathrm{mM}$ potassiumphosphate buffer, containing $300 \mathrm{mM} \mathrm{NaCl}, \mathrm{pH} 8.3$ ). The mix was incubated at $37^{\circ} \mathrm{C}$ during $120 \mathrm{~min}$ and the reaction was quenched by addition of $100 \mu \mathrm{L} 0.1 \mathrm{M} \mathrm{HCl}$. The released hippuric acid (HA) was quantified by RP-HPLC (model SPE-MA10AVP, Shimadzu, Kyoto, Japan) on a C18 column (Tracel excel, 120 ODSA $5 \mu \mathrm{m}$, Teknokroma, Barcelona, Spain). The injection volume was $50 \mu \mathrm{L}$ and the flow rate 0.8 $\mathrm{mL} / \mathrm{min}$ using an acetonitrile gradient from 20 to $60 \%$ in $0.1 \%$ trifluoroacetic acid (TFA) (v/v) for $26 \mathrm{~min}$. The HHL and HA were monitored at $228 \mathrm{~nm}$ and eluted at 8.30 and 15.70 min respectively. All determinations were carried out at least in triplicate. The $\mathrm{IC}_{50}$ value was defined as the concentration of peptide $(\mu \mathrm{M})$ required to reduce the HA peak by $50 \%$ (indicating 50\% inhibition of ACE activity). All determinations were performed at least in triplicate.

\section{Results and Discussion}

\subsection{Fractionation of the hydrolysate}

The hydrolysate of squid gelatin was ultrafiltered through an ultrafiltration membrane with a molecular weight cut-off of $10 \mathrm{kDa}$ to enrich it in low molecular weight peptides, which have been associated with antioxidant activity (Gómez-Guillén, López-Caballero, Alemán, López de Lacey, Giménez and Montero, 2010).

The ultrafiltrate (UF-10) was then fractionated by size exclusion chromatography and four fractions were collected based on the chromatogram, named I, II, III and IV, respectively (Figure 1). Both the amino acid composition and antioxidant activity of the separated fractions were evaluated.

Antioxidant activity and amino acid composition of fractions 
The antioxidant activity of both UF-10 and peptide fractions was evaluated by FRAP and ABTS (Figure 2). Reducing power is a measure of global antioxidant capacity as antioxidants show reducing power in redox reactions (Cumby, Zhong, Naczk \& Shahidi, 2008). Although all the peptide fractions showed a ferric reducing ability significantly higher than that of UF-10 (Fig. 2A), FRAP values were noticeably higher in fractions FI, FII and FIII. The highest reducing power was found in fraction FIII, with a 6-fold increase compared to UF-10.

Regarding ABTS radical scavenging ability, all the fractions showed significantly lower VCEAC values than UF-10 (Fig. 2B). Among the peptide fractions, FIII showed the highest radical scavenging ability, followed by fractions FII, FI and FIV. An increase of FRAP and ABTS values with decreasing the molecular weight from fractions I to III was found in this study. However, fraction FIV, with the lowest molecular weight, showed the lowest antioxidant activity measured by both ABTS and FRAP, probably due to the presence of large number of free amino acid and small peptides without antioxidant capacity. Wu, Chen, and Shiau, (2003) and Je, Park, and Kim, (2005) fractioned by molecular mass a protein hydrolysate from mackerel and hoki frame respectively and also found the lowest antioxidant activity on the fraction with lowest molecular weight.

The fractions collected were subjected to amino acid composition analysis (Table 1) in order to determine the possible effect of the amino acid profile on the antioxidant activity. Although the major constituent amino acids of all the fractions were Gly, Glu, Ala, Pro and Hyp, some differences were remarkable. Thus, Asp content in FI and II was 2-fold higher than in FIII and FIV. Glu content was noticeably higher in FIII, whereas FIV showed the highest contents of Ala, Leu, Phe or Pro. Based only on the content of these amino acids in the four fractions, one could expect slight differences in 
the antioxidant activity of these fractions. However, as described above, FIII clearly showed the highest antioxidant activity measured by both FRAP and ABTS. In agreement with other studies, besides the amino acid profile and the molecular weight, the amino acid sequence of the peptides may greatly contribute to generate the antioxidant activity observed (Suetsuna, Ukeda, \& Ochi, 2000; Ren et al., 2008).

\subsection{Identification of compounds by LC-MS/MS}

Fraction FIII was collected and subjected to LC-ESI-IT-MS/MS to identify putative antioxidant peptides. Two major peaks were observed in the LC chromatogram (Figure 3A). Figure 3B shows the MS spectrum of the peak 1, where the ion of $\mathrm{m} / \mathrm{z} 952.42$ was the most abundant. The collision induced fragmentation of this compound is shown in Figure 3C. A major ion of m/z 702.32 and several fragments that differed in units of $\mathrm{m} / \mathrm{z} 146$ were observed in the mass spectrum, which would correspond to the loss of a unit of dehydrofucose. According to König and Leary (1998), this finding largely suggested that the compound with $\mathrm{m} / \mathrm{z} 952.42$ could be mostly comprised by the carbohydrate fucose. Other minor components present also in the $\mathrm{m} / \mathrm{z} 952$ ion could be carbohydrate units or amino acids. Collagen structure has been shown to content carbohydrate units covalently joined to amino acid residues (Wells-Knecht, Lyons, McCance, Thorpe, Feather, \& Baynes, 1994; Knott \& Bailey, 1998; Paschalis, Verdelis, Doty, Boskey, Mendelsohn, \& Yamauchi, 2001; Muyonga, Cole \& Duodu, 2004). The carbohydrate units more frequently found in collagen are glucose and galactose, as well as mannose, fucose, sialic acid or hexosamines in small amounts (Spiro, 1969; de PazLugo, 2006). In previous studies, a significantly higher carbohydrate content has been reported in squid gelatin when compared to gelatin extracted from other marine species (Giménez et al., 2009), and we hypothesize that the presence of glycosylated peptides 
may play an important role in the higher antioxidant activity observed in squid gelatin (Giménez et al., 2009). In connection with this, glycoproteins have been reported to be able to scavenge free radicals such as 1,1-Diphenyl-2-picrylhydrazyl radical (DPPH) or oxygen radicals as a consequence of the high polarity in the carbohydrate part of the whole glycoprotein molecule (Oh \& Lim, 2008).

Figure 4A shows the MS spectrum of the second most abundant component from the fraction FIII (peak 2 in Figure 3A), which contained a major ion at m/z 1410.63 Da. De novo sequencing of this compound with $\mathrm{m} / \mathrm{z} 1410.63 \mathrm{Da}$ was performed by manual interpretation of the ion series in the fragmentation spectrum (Figure 4B) and the sequence was determined to be Gly-Pro-X-Gly-X-X-Gly-Phe-X-Gly-Pro-X-Gly-X-Ser, with the positions marked as $\mathrm{X}$ occupied by either Hyp or Leu, since the MS/MS analysis performed could not differentiate between the molecular weight of Hyp (131.17 Da) and Leu (131.13 Da). In view of this result, FIII was subjected to MALDI-TOF MS analysis. However, no peak masses were detected (data not shown).

As it was not feasible to distinguish between Hyp and Leu, tentatively three peptide structures were proposed: (I) Leu in all the positions marked as X (Gly-Pro-Leu-GlyLeu-Leu-Gly-Phe-Leu-Gly-Pro-Leu-Gly-Leu-Ser), (II) Hyp in all the positions marked as $\mathrm{X}$ (Gly-Pro-Hyp-Gly-Hyp-Hyp-Gly-Phe-Hyp-Gly-Pro-Hyp-Gly-Hyp-Ser) and (III) Leu only in the fourth X position (Gly-Pro-Hyp-Gly-Hyp-Hyp-Gly-Phe-Leu-Gly-ProHyp-Gly-Hyp-Ser). This third structure was proposed based on homology between the sequence and those described as collagen in the NCBInr database, as well as on the amino acid composition of the fraction FIII. As the content of Hyp was over 3-fold higher than that of Leu in this peptide fraction (Table 1), one residue of Leu could be expected every 6 residues of Hyp. Furthermore, Pro and Hyp frequently follow each other and the Gly-Pro-Hyp sequences make up about $10 \%$ of the collagen molecule 
(Nimni \& Harkness, 1988). As it can be observed, these sequences have Gly every three amino acids, typical from collagen molecule where glycine represents $33-34 \%$ of the amino acid residues.

The three proposed peptides were further synthesized to test the antioxidant activity by both ferric reducing ability (FRAP) and ABTS radical scavenging capacity.

\subsection{Antioxidant activity of synthetically derived peptides}

Ferric reducing power and ABTS radical scavenging ability of the proposed peptides are shown in Figure 5. Peptide I (with Leu in all the positions marked as X) showed both the highest FRAP (Figure 5A) and ABTS values (Figure 5B). Total or partial replacement of Leu by Hyp residues to obtain peptides II and III, respectively, gave rise to a 2-fold decrease both in reducing power and radical scavenging ability. Therefore, the presence of Leu residues in these sequences seems to play an important role in the antioxidant activity of the peptides. Dávalos, Miguel, Bartolomé and López-Fandiño (2004) working on the activity of individual amino acids reported that, Trp, Tyr, Met showed the highest antioxidant activity, followed by Cys, His and Phe. The rest of the amino acids did not show any antioxidant activity. However, many peptides have been described to have antioxidant capacity without containing any of the above mentioned proton-donating amino acid residues in their sequences. Thus, Rajapkase et al. (2005) reported two antioxidant peptides, Asn-Gly-Leu-Glu-Gly-Leu-Lys and Asn-Ala-AspPhe-Gly-Leu-Asn-Gly-Leu-Glu-Gly-Leu-Ala isolated from giant squid muscle protein. Li, Chen, Wang, Ji, and Wu (2007) identified the peptide Gln-Gly-Ala-Arg, which exhibited the highest antioxidant activity from porcine skin collagen hydrolysates. Therefore, the amino acid sequence of the peptide might play an important role in its activity (Ren et al., 2008; Suetsuna et al., 2000). Leu has been reported to enhance the 
scavenging activities of peptides (Park et al., 2001; Li et al., 2007), as it has been also shown in this study. Furthermore, Gly and Pro have been suggested to play an important role in radical scavenging ability of some peptides (Mendis et al., 2005b; Chen et al., 1996; Rajapakse et al., 2005). The side-chain of Gly consists of a single hydrogen atom and may confer high flexibility on the peptide backbone. Moreover, the pyrrolidine ring of Pro tends to interrupt the secondary structure of the peptide imposing conformational constraints. As a consequence, the presence of these amino acids may increase the availability of the amino acid residues of the peptide sequences to act as antioxidants.

Peptide I had the most hydrophobic sequence. With the exception of Ser, all the amino acid residues were hydrophobic (Leu, Pro, Phe), with leucine composing approximately $40 \%$ of the peptide sequence. Since hydrophobicity of antioxidants is important for accessibility to hydrophobic targets (Chen et al., 1996), it may be presumed that the presence of leucine in the peptide sequence may contribute to lipid oxidation inhibition by increasing solubility of peptides in lipid.

When the antioxidant capacity of the synthetic peptides was compared to that described for the fraction FIII, only the peptide I showed FRAP values similar to those found in F III (38.2 $\mu \mathrm{mol} \mathrm{FeEq} / \mathrm{g}$ on average), whereas ferric reducing power of peptides II and III was about 2-fold lower. Regarding ABTS, synthetic peptides showed between 3- and 4fold lower ABTS values than those described for FIII. Therefore, these sequences, in spite of corresponding to one of the most abundant compounds found in fraction FIII and the high content of Leu residues in the sequence of peptide I, were not directly responsible for the radical scavenging capacity observed in this fraction. The ABTS radical scavenging capacity observed in FIII may be attributed to other peptidic sequences with antiradical capacity although present in smaller quantities, together with the likely presence of glycosylated peptides. Other peptides isolated from skin gelatin 
hydrolysates of marine species have demonstrated noticeable free-radical scavenging activity (Mendis et al., 2005ab; Li et al., 2007).

\subsection{ACE inhibitory activity of synthetically derived peptides}

The fractions III and IV also presented ACE inhibitory capacity, although it was low and it was not possible to determine the $\mathrm{IC}_{50}$ values (amount of sample required to inhibit $50 \%$ of the ACE activity). However, the capacity to inhibit the ACE was found to be very high in the synthesized peptides. The $\mathrm{IC}_{50}$ of the peptides is shown in table 2 . The molecular weight of these peptides was approximately of $1400 \mathrm{Da}$, which is on the average molecular weight proposed by Zeng, Li, Chen, Li and Wu (2005) for ACE inhibitory peptides from aquatic products, mostly below $1500 \mathrm{Da}$. The ACE inhibitory capacity was highly dependent on the peptide sequence. Peptide I showed the most potent effect $\left(\mathrm{IC}_{50} 90.03 \mu \mathrm{M}\right)$, followed by peptide III ( $\left.\mathrm{IC}_{50} 256.82 \mu \mathrm{M}\right)$. However, peptide II did not show any ACE inhibitory activity. Although the structure-activity relationship of food derived ACE inhibitory peptides has not yet been fully established, correlation among different peptide inhibitors of ACE indicate that binding to this enzyme is strongly influenced by the C-terminal tripeptide sequence of the substrate or inhibitor. ACE appears to prefer substrates or competitive inhibitors that mainly have hydrophobic (aromatic or branched side chains) amino acid residues at the three Cterminal positions (Murray \& FitzGerald, 2007). Therefore, the presence of Leu and Gly in peptide I at the second and third positions from carboxyl-terminus seems to play an important role in the ACE inhibitory activity. Although peptides II and III shared the same tripeptide sequence at the carboxyl terminus, peptide II was inactive as ACE inhibitor (Table 2). Wu, Aluko and Nakai (2006) reported that in case of long-chain peptides (more than five residues), as in this case, the C-terminal tetrapeptide residues 
were more important to their ACE-inhibitory activity than the C-terminal tripeptide sequence. However, this finding does not either explain the difference between peptides II and III, since they also have the same C-terminal tetrapeptide sequence. Moreover, several authors have suggested that in case of long peptides, it is expected that peptide conformation, i.e. the structure adopted in the specific environment of the binding site will influence binding to ACE, and therefore the ACE inhibitory capacity of these peptides (FitzGerald \& Meisel, 2000; Meisel, 2003; Meisel, Walsh, Murray \& FitzGerald, 2005). Peptides II and III differs in the seventh position from the carboxyl terminus (Hyp in peptide II; Leu in peptide III). The different polarity of these two residues may involve conformational changes in the peptide backbone that influence the ACE inhibitory capacity.

The antihypertensive effects of collagen hydrolysates prepared from various sources and the isolation of several ACE inhibitory peptides from those hydrolysates have been reported in previous works (Byun \& Kim, 2001; Fahmi et al., 2004; Zhao et al., 2007; Saiga et al., 2008; Ichimura, Yamanaka, Otsuka, Yamashita \& Maruyama, 2009). However, the use of different methods and their associated modifications to test ACE inhibitory capacity makes difficult the direct comparison of $\mathrm{IC}_{50}$ values from different studies when some reports do not detail the number of enzyme units used in the inhibition analysis or do not include an $\mathrm{IC}_{50}$ value for an ACE inhibitory standard such as Captopril@ (Murray, Walsh \& FitzGerald, 2004). As an example, the dipeptide AlaPro has been reported with $\mathrm{IC}_{50}$ values ranging from 29 to $230 \mu \mathrm{M}$ (Wyvratt \& Patchett, 1985; Ichimura, Hu, Aita \& Maruyama, 2003; Fuglsang, Nilsson \& Nyborg, 2003). Another example is Ala-Val-Pro-Tyr-Pro-Gln-Arg, obtained from $\beta$-casein f (177-183), with reported $\mathrm{IC}_{50}$ values ranging from 15 to $274 \mu \mathrm{M}$ (Nurminen, 1999; PihlantoLeppälä, Rokka \& Korhonen, 1998). In connection with this, Wu et al. (2002) have 
reported that the spectrophotometric assay described by Cushman and Cheung (1971), widely used for testing ACE inhibition of gelatin hydrolysates, tends to overestimate the amount of HA produced during ACE-catalyzed reactions. Having this in mind, $\mathrm{IC}_{50}$ values of the most potent inhibitor (peptide I), were between 26- and 1.5-fold higher than those reported for ACE inhibitory peptides derived from different food proteins, tested in similar conditions (Centeno et al., 2006; He, Chen, Sun, Zhang \& Zhou, 2006; Tsai, Lin, Chen, \& Pan, 2006; Tauzin, Miclo, \& Gaillard, 2002). Therefore, peptide I could be considered as a moderate ACE inhibitory peptide. Nevertheless, these $\mathrm{IC}_{50}$ values are still far from the $\mathrm{IC}_{50}$ value obtained for the synthetic ACE inhibitor enalapril in this study (7.34 $\mu \mathrm{M}$, Table 2$)$ or that reported for captopril $(0.022 \mu \mathrm{M})(\mathrm{WHO}, 2003)$. However, it is known that these drugs can cause adverse side effects (Messerli, 1999; Tabacova \& Kimmel, 2001). Furthermore, some ACE inhibitors have been reported to have better in vivo properties than the efficacy levels extrapolated from in vitro effects (Vermeirssen, van Camp \& Verstraete, 2004), probably due to the higher affinity of these peptides for tissue and slower elimination of them than of a drug compound. It should be pointed out that the sequence Gly-Phe-Hyp-Gly-Pro that takes part of the inactive ACE inhibitory peptide II, has been reported to significantly decrease the blood pressure of the spontaneously hypertensive rats (SHRs) with long-term efficiency when orally administered at both 30 and $10 \mathrm{mg} / \mathrm{kg}$ (Ichimura et al., 2009). Furthermore, the dipeptide Gly-Pro, that exists in collagen as a large number of repeated sequences and is contained in all the proposed peptides (I, II and III), also showed antihypertensive effect in SHRs (Ichimura et al., 2009). These findings suggest that the antihypertensive effect of peptides I, II and III might improve after oral administration due to the release of more active sequences by gastrointestinal digestion. 


\section{Conclusions}

A squid gelatin hydrolysate was separated by ultrafiltration and size-exclusion chromatography and all the peptide fractions showed a ferric reducing power significantly higher than the hydrolysate. In contrast, the ABTS radical scavenging was higher in the gelatin hydrolysate than in the different fractions. The presence of Leu residues in the peptide sequence (Gly-Pro-Leu-Gly-Leu-Leu-Gly-Phe-Leu-Gly-ProLeu-Gly-Leu-Ser), seem to play an important role in their antioxidant and ACEinhibitory activity. Furthermost, the presence of glycosylated peptides may contribute to the high antioxidant activity of the squid gelatin hydrolysate.

\section{References}

Adler-Nissen, J. (1977). Enzymatic hydrolysis of food proteins. Process Biochemistry, 8, 18-32.

Atkinson, A.B., \& Robertson, J.I.S. (1979). Captopril in the treatment of clinical hypertension and cardiac failure. Lancet, 2, 836-839.

Benzie, I. F. F., \& Strain, J. J. (1996). The ferric reducing ability of plasma (FRAP) as a measure of "antioxidant power": the FRAP assay. Analytical Biochemistry, 239, 70-76.

Butterfield, D.A., Castegna, A., Pocernich, C.B., Drake, J., Scapagnini, G., \& Calabrese, V. (2002). Nutritional approaches to combat oxidative stress in Alzheimer's disease. Journal of Nutritional Biochemistry, 13, 444-461.

Byun, H.G., \& Kim, S.K. (2001). Purification and characterization of angiotensin I converting enzyme (ACE) inhibitory peptides from Alaska pollack (Theragra chalcogramma) skin. Process Biochemistry, 36, 1155-1162.

Centeno, J.M., Burguete, M.C., Castelló-Ruiz, M., Enrique, M., Vallés, S., Salom, J.B., Torregrosa, G., Marcos, J.F., Alborch, E., \& Manzanares, P. (2006). Lactoferricin- 
related peptides with inhibitory effects on ACE-dependent vasoconstriction. Journal of Agricultural and Food Chemistry, 54, 5323-5329.

Chen, H.-M., Muramoto, K., Yamauchi, F., \& Nokihara, K. (1996). Antioxidant Activity of Designed Peptides Based on the Antioxidative Peptide Isolated from Digests of a Soybean Protein. Journal of Agricultural and Food Chemistry, 44, 2619-2623.

Cumby, N., Zhong, Y., Naczk, M., \& Shahidi, F. (2008). Antioxidant activity and water-holding capacity of canola protein hydrolysates. Food Chemistry, 109, 144-148.

Cushman, D.W., \& Cheung, H.S. (1971). Spectrophotometric assay and properties of the angiotensin-converting enzyme of rabbit lung. Biochemical Pharmacology, 20, $1637-1648$.

Dávalos, A., Miguel, M., Bartolomé, B., \& López-Fandiño, R. (2004). Antioxidant activity of peptides derived from egg white proteins by enzymatic hydrolysis. Journal of Food Protection, 67, 1939-1944.

De Paz-Lugo, P. (2006). Estimulación de la síntesis de colágeno en cultivos celulares. Posible tratamiento en enfermedades degenerativas mediante la dieta. Tesis. http://www.imsersomayores.csic.es/documentos/documentos/tesis-paz-estimulacion.pdf Fahmi, A., Morimura, S., Guo, H.C., Shigematsu, T., Kida, K. \& Uemura, Y. (2004). Production of angiotensin I converting enzyme inhibitory peptides from sea bream scales. Process Biochemistry, 39, 1195-1200.

Fitzgerald, R.J., \& Meisel, H. (2000). Milk protein-derived peptide inhibitors of angiotensin-I-converting enzyme. British Journal of Nutrition, 84, S33-S37.

Fuglsang, A., Nilsson, D., \& Nyborg, N.C.B. (2003). Characterization of new milkderived inhibitors of angiotensin converting enzyme In Vitro and In Vivo. Journal of Enzyme Inhibition and Medicinal Chemistry, 18, 407-412. 
Giménez, B., Alemán, A., Montero, P., \& Gómez-Guillén, M.C. (2009). Antioxidant and functional properties of gelatin hydrolysates obtained from skin of sole and squid. Food Chemistry, 114, 976-983.

Gómez-Guillén, M.C., López-Caballero, M.E., Alemán, A., López de Lacey, A., Giménez, B., \& Montero, P. (2010). Antioxidant and antimicrobial peptide fractions from squid and tuna skin gelatin. In Le Bihan, E., Sea by-products as raw material: new ways of application (pp. 89-115). Kerala: Transworld Research Network.

Goodfriend, T.L., Elliott, M.E., \& Catt, K.J. (1996). Angiotensin receptors and their antagonists. New England Journal of Medicine, 334, 1649-1654.

He, H.L., Chen, X.L., Sun, C.Y., Zhang, Y.Z., \& Zhou, B.C. (2006). Analysis of novel angiotensin-i-converting enzyme inhibitory peptides from protease-hydrolyzed marine shrimp Acetes chinensis. Journal of Peptide Science, 12, 726-733.

Hernández-Ledesma, B., Dávalos, A., Bartolomé, B., \& Amigo, L. (2005). Preparation of antioxidant enzymatic hydrolysates from $\alpha$-lactalbumin and $\beta$-lactoglobulln. Identification of active peptides by HPLC-MS/MS. Journal of Agricultural and Food Chemistry, 53, 588-593.

Ichimura, T., Hu, J., Aita, D.Q., \& Maruyama, S. (2003). Angiotensin I-Converting Enzyme Inhibitory Activity and Insulin Secretion Stimulative Activity of Fermented Fish Sauce. Journal of Bioscience and Bioengineering, 96, 496-499.

Ichimura, T., Yamanaka, A., Otsuka, T., Yamashita, E., \& Maruyama, S. (2009). Antihypertensive effect of enzymatic hydrolysate of collagen and gly-pro in spontaneously hypertensive rats. Bioscience, Biotechnology and Biochemistry, 73, 2317-2319. 
Je, J.Y., Park, P.J., \& Kim, S.K. (2005). Antioxidant activity of a peptide isolated from Alaska pollack (Theragra chalcogramma) frame protein hydrolysate. Food Research International, 38, 45-50.

Kim, S.K., Byun, H.G., Park, P.J., \& Shahidi, F. (2001). Angiotensin I converting enzyme inhibitory peptides purified form bovine skin gelatin hydrolysate. Journal of Agricultural and Food Chemistry, 49, 2992-2997.

Kim, S.K., \& Mendis, E. (2006). Bioactive compounds from marine processing byproducts - A review. Food Research International, 39, 383-393.

Knott, L., \& Bailey, A.J. (1998). Collagen cross-links in mineralizing tissues: A review of their chemistry, function, and clinical relevance. Bone, 22, 181-187.

König, S., \& Leary, J.A. (1998). Evidence for linkage position determination in cobalt coordinated pentasaccharides using ion trap mass spectrometry. Journal of the American Society for Mass Spectrometry, 9, 1125-1134.

Li, B., Chen, F., Wang, X., Ji, B., \& Wu, Y. (2007). Isolation and identification of antioxidative peptides from porcine collagen hydrolysate by consecutive chromatography and electrospray ionization-mass spectrometry. Food Chemistry, 102, $1135-1143$.

Lin, L., \& Li, B. (2006). Radical scavenging properties of protein hydrolysates from Jumbo flying squid (Dosidicus eschrichitii Steenstrup) skin gelatin. Journal of the Science of Food and Agriculture, 86, 2290-2295.

Meisel, A. (2003). Quality of life and end-of-life decisionmaking. Quality of Life Research, 12, 91-94.

Meisel, H., Walsh, D.J., Murray, B.A., \& FitzGerald, R.J. (2005). Factors on the body’s regulation system. In Y. Mine \& F. Shahidi, Nutraceutical proteins and peptides in health and disease (pp. 269-315). New York: CRC Press. 
Mendis, E., Rajapakse, N., Byun, H.G., \& Kim, S.K. (2005a). Investigation of jumbo squid (Dosidicus gigas) skin gelatin peptides for their in vitro antioxidant effects. Life Science, 70, 2166-2178.

Mendis, E., Rajapakse, N., \& Kim, S.K. (2005b). Antioxidant properties of a radicalscavenging peptide purified from enzymatically prepared fish skin gelatin hydrolysate. Journal of Agricultural and Food Chemistry, 53, 581-587.

Messerli, F. H. (1999). Hypertension and sudden cardiac death. American Journal of Hypertension, 12, 181-188.

Murray, B.A., \& FitzGerald, R.J. (2007). Angiotensin converting enzyme inhibitory peptides derived from food proteins: Biochemistry, bioactivity and production. Current Pharmaceutical Design, 13, 773-791.

Murray, B.A., Walsh, D.J., \& FitzGerald, R.J. (2004). Modification of the furanacryloyl-L-phenylalanylglycylglycine assay for determination of angiotensin-Iconverting enzyme inhibitory activity. Journal of Biochemical and Biophysical Methods, 59, 127-137.

Muyonga, J.H., Cole, C.G.B., \& Duodu, K.G. (2004). Fourier transform infrared (FTIR) spectroscopic study of acid soluble collagen and gelatin from skins and bones of young and adult Nile perch (Lates niloticus). Food Chemistry, 86, 325-332.

Nimni, M.E. \& Harkness, R.D. (1988). Molecular structures and function of collagen. In M.E. Nimni, Collagen Biochemistry (pp. 1-77), Boca Raton: CRC Press. Nurminen, M.L. (1999). Central nervous system as a target for the new antihypertensive agents. Duodecim, 115, 2267-2273.

Oh, P.S. \& Lim, K.T. (2008). Antioxidant activity of Dioscorea batatas Decne glycoprotein. European Food Research and Technology, 226, 507-515. 
Pahor, M., Psaty, B.M., Alderman, M.H., Applegate, W.B., Williamson, J.D., \& Furberg, C.D. (2000). Therapeutic benefits of ACE inhibitors and other antihypertensive drugs in patients with type 2 diabetes. Diabetes Care, 23, 888-892.

Park, P.J., Jung, W.K., Nam, K.S., Shahidi, F., \& Kim, S.K. (2001). Purification and characterization of antioxidative peptides from protein hydrolysate of lecithin-free egg yolk. Journal of the American Oil Chemists' Society, 78, 651-656.

Paschalis, E.P., Verdelis, K., Doty, S.B., Boskey, A.L., Mendelsohn, R., \& Yamauchi, M. (2001). Spectroscopic characterization of collagen cross-links in bone. Journal of Bone and Mineral Research, 16, 1821-1828.

Pihlanto-Leppälä, A., Rokka, T., \& Korhonen, H. (1998). Angiotensin I converting enzyme inhibitory peptides derived from bovine milk proteins. International Dairy Journal, 8, 325-331.

Pryor, W.A. (1982). Free radical biology: Xenobiotics, cancer, and aging. Annals of the New York Academy of Sciences, 393, 1-22.

Rajapakse, N., Mendis, E., Byun, H.-G., \& Kim, S.K. (2005). Purification and in vitro antioxidative effects of giant squid muscle peptides on free radical-mediated oxidative systems. Journal of Nutritional Biochemistry, 16, 562-569.

Re, R., Pellegrini, N., Proteggente, A., Pannala, A., Yang, M., \& Rice-Evans, C. (1999). Antioxidant activity applying an improved ABTS radical cation decolorization assay. Free Radical Biology and Medicine, 26, 1231-1237.

Ren, J., Zhao, M., Shi, J., Wang, J., Jiang, Y., Cui, C., Kakuda Y. \& Xue, S.J. (2008). Purification and identification of antioxidant peptides from grass carp muscle hydrolysates by consecutive chromatography and electrospray ionization-mass spectrometry. Food Chemistry, 108, 727-736. 
Saiga, A., Iwai, K., Hayakawa, T., Takahata, Y., Kitamura, S., Nishimura, T., \& Morimatsu, F. (2008). Angiotensin I-converting enzyme-inhibitory peptides obtained from chicken collagen hydrolysate. Journal of Agricultural and Food Chemistry, 56, 9586-9591.

Spiro, R.G. (1969). Characterization and quantitative determination of the hydroxylysine-linked carbohydrate units of several collagens. The Journal of Biological Chemistry, 244(3), 602-612.

Suetsuna, K., Ukeda, H., \& Ochi, H. (2000). Isolation and characterization of free radical scavenging activities peptides derived from casein. Journal of Nutritional Biochemistry, 11, 128-131.

Tabacova, S.A., \& Kimmel, C.A. (2001). Enalapril: Pharmacokinetic/dynamic inferences for comparative developmental toxicity. Reproductive Toxicology, 15, 467478.

Tauzin, J., Miclo, L., \& Gaillard, J.L. (2002). Angiotensin-I-converting enzyme inhibitory peptides from tryptic hydrolysate of bovine aS2-casein. FEBS Letters, 531, 369-374.

Tsai, J.S., Lin, T.C., Chen, J.L., \& Pan, B.S. (2006). The inhibitory effects of freshwater clam (Corbicula fluminea, Muller) muscle protein hydrolysates on angiotensin I converting enzyme. Process Biochemistry, 41, 2276-2281.

Vermeirssen, V., van Camp, J., \& Verstraete, W. (2004). Bioavailability of angiotensin I-converting enzyme inhibitory peptides. British Journal of Nutrition, 92, 357-366.

Wells-Knecht, K.J., Lyons, T.J., McCance, D.R., Thorpe, S.R., Feather, M.S., \& Baynes, J.W. (1994). 3-Deoxyfructose concentrations are increased in human plasma and urine in diabetes. Diabetes, 43, 1152-1156. 
Witherow, F.N., Helmy, A., Webb, D.J., Fox, K.A.A., \& Newby, D.E. (2001). Bradykinin contributes to the vasodilator effects of chronic angiotensin-converting enzyme inhibition in patients with heart failure. Circulation, 104, 2177-2181.

World Health Organisation. Diet, nutrition and the prevention of chronic diseases. A Report of a Joint World Health Organisation/Food and Agriculture Organisation Expert Consultation. Geneva, WHO 2003.

Wu, C.H., Chen, H.M., \& Shiau, C.Y. (2003). Free amino acids and peptides as related to antioxidant properties in protein hydrolysates of mackerel (Scomber austriasicus), Food Research International, 36, 949-957.

Wu, J., Aluko, R. E., \& Muir, A. D. (2002). Improved method for direct highperformance liquid chromatography assay of angiotensin-converting enzyme-catalyzed reactions. Journal of Chromatography A, 950, 125-130.

Wu, J., Aluko, R.E., \& Nakai, S. (2006). Structural requirements of angiotensin Iconverting enzyme inhibitory peptides: Quantitative structure-activity relationship study of Di- and tripeptides. Journal of Agricultural and Food Chemistry, 54, 732-738.

Wyvratt, M.J., \& Patchett, A.A. (1985). Recent developments in the design of angiotensin-converting enzyme inhibitors. Medicinal Research Reviews, 5, 483-531.

Zeng, M., Li, B., Chen, S., Li, L., \& Wu, Y. (2005). Study on enzymic hydrolytic conditions of skin collagen from Oreochromis niloticu. Chinese Journal of Marine Drugs, 24, 24-29.

Zhao, Y., Li, B., Liu, Z., Dong, S., Zhao, X., \& Zeng, M. (2007). Antihypertensive effect and purification of an ACE inhibitory peptide from sea cucumber gelatin hydrolysate. Process Biochemistry, 42, 1586-1591. 


\section{Legends to Figures}

Figure 1. Size-exclusion chromatogram of UF-10.

Figure 2. Ferric reducing power (FRAP) (2A) and ABTS radical scavenging capacity (2B) of UF-10 and the fractions FI, FII, FIII and FIV separated by size exclusion chromatography.

Figure 3. LC chromatogram of fraction FIII (3A), MS spectrum of the peak 1 (3B) and MS/MS spectrum of the compound with $\mathrm{m} / \mathrm{z} 952.42$ (3C).

Figure 4. MS spectrum of the peak 2 present in the LC chromatogram of fraction FIII (4A) and MS/MS spectrum of the compound with m/z 1410.63 (4B).

Figure 5. Ferric reducing power (FRAP) (5A) and ABTS radical scavenging capacity (5B) of the synthetic peptides. 


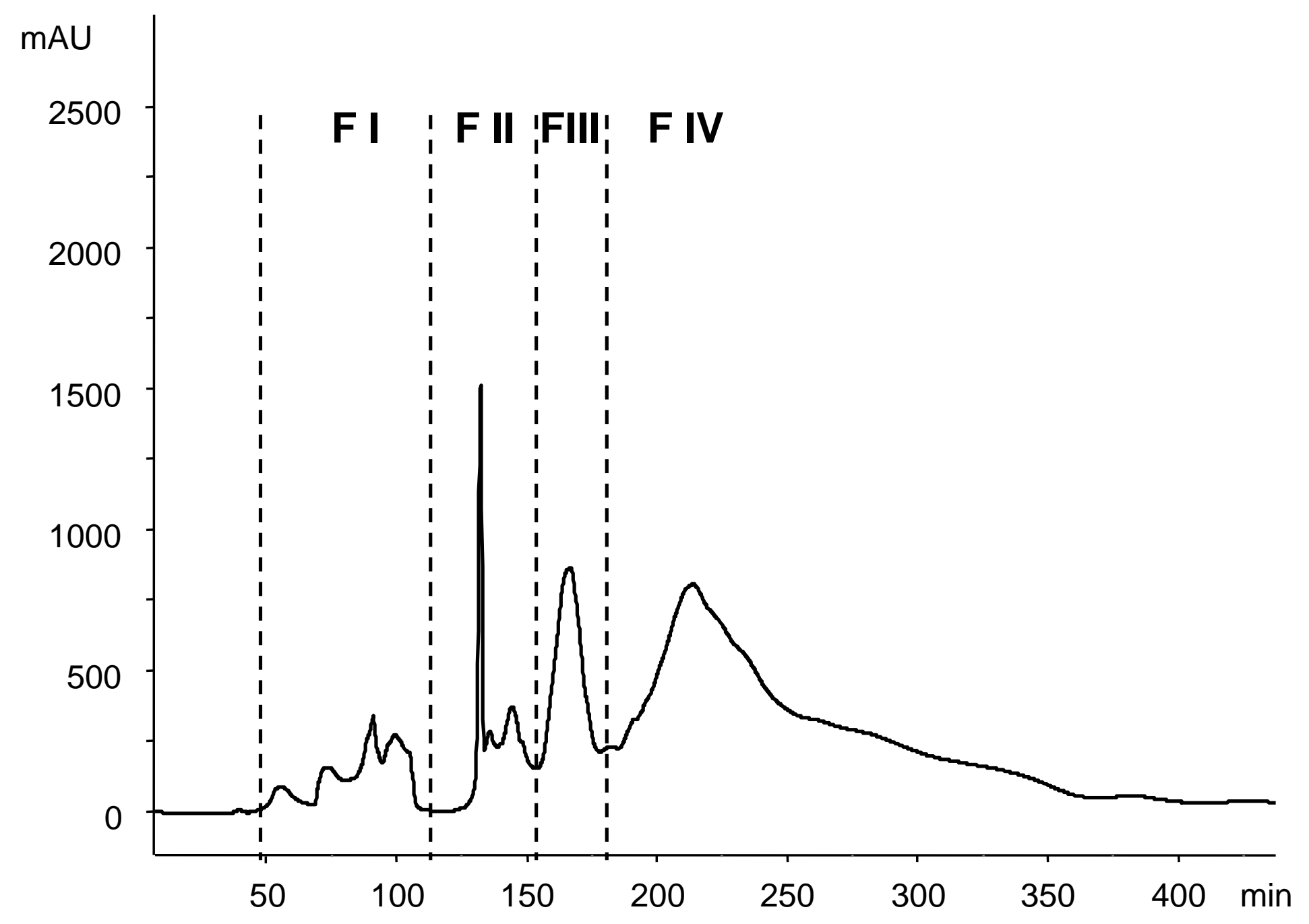

Fig. 1 

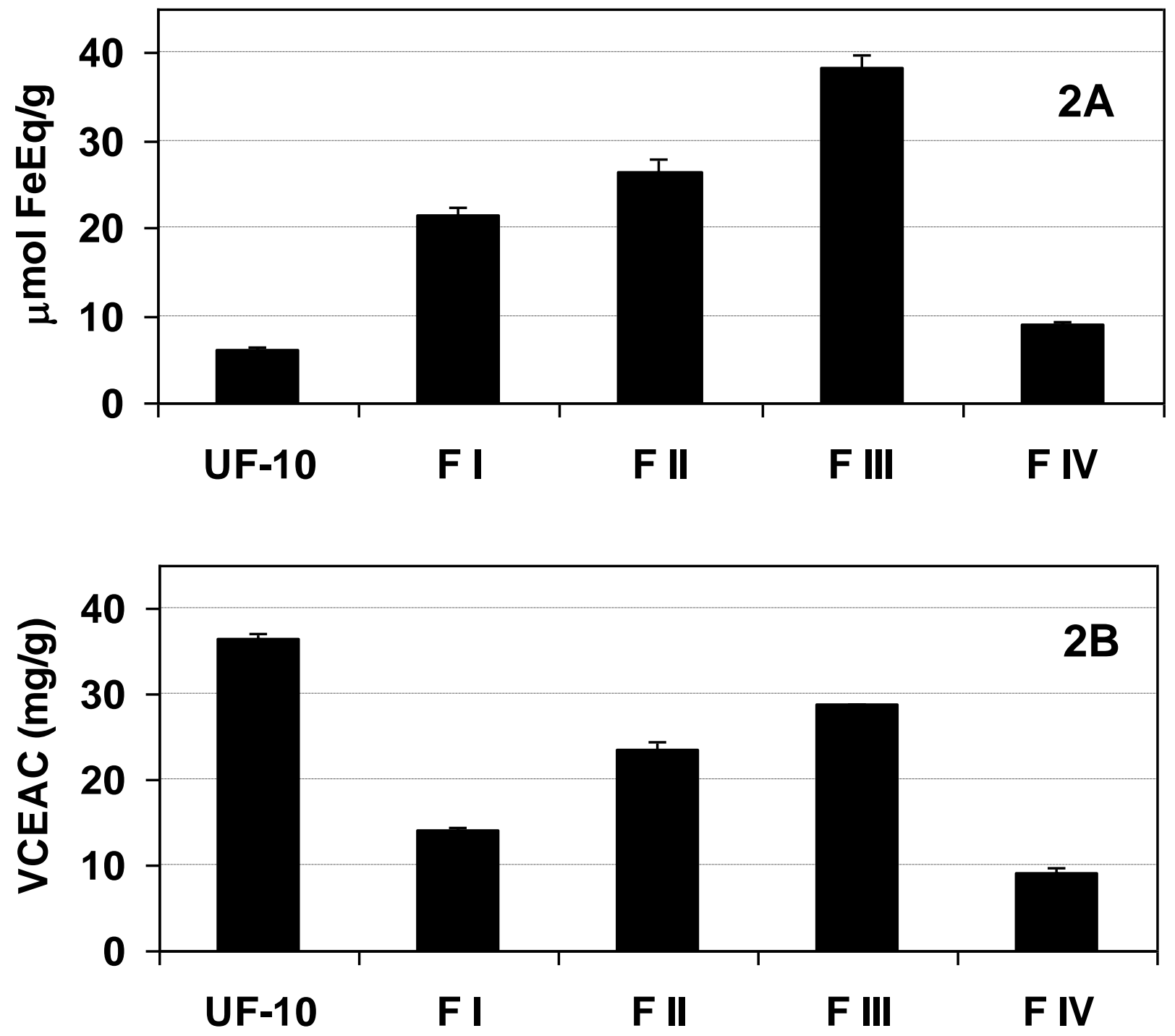

Fig. 2 

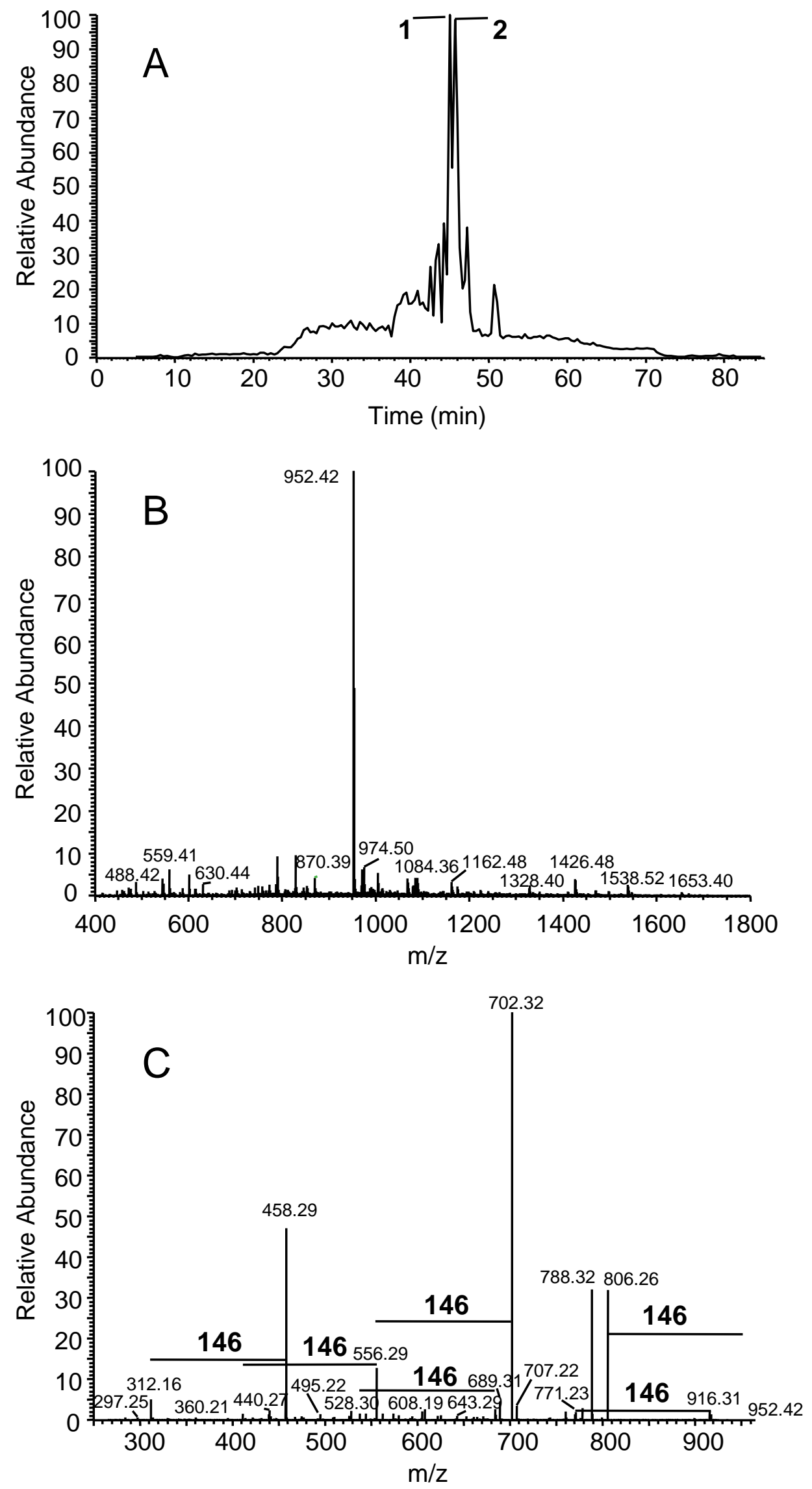

Figure 3 

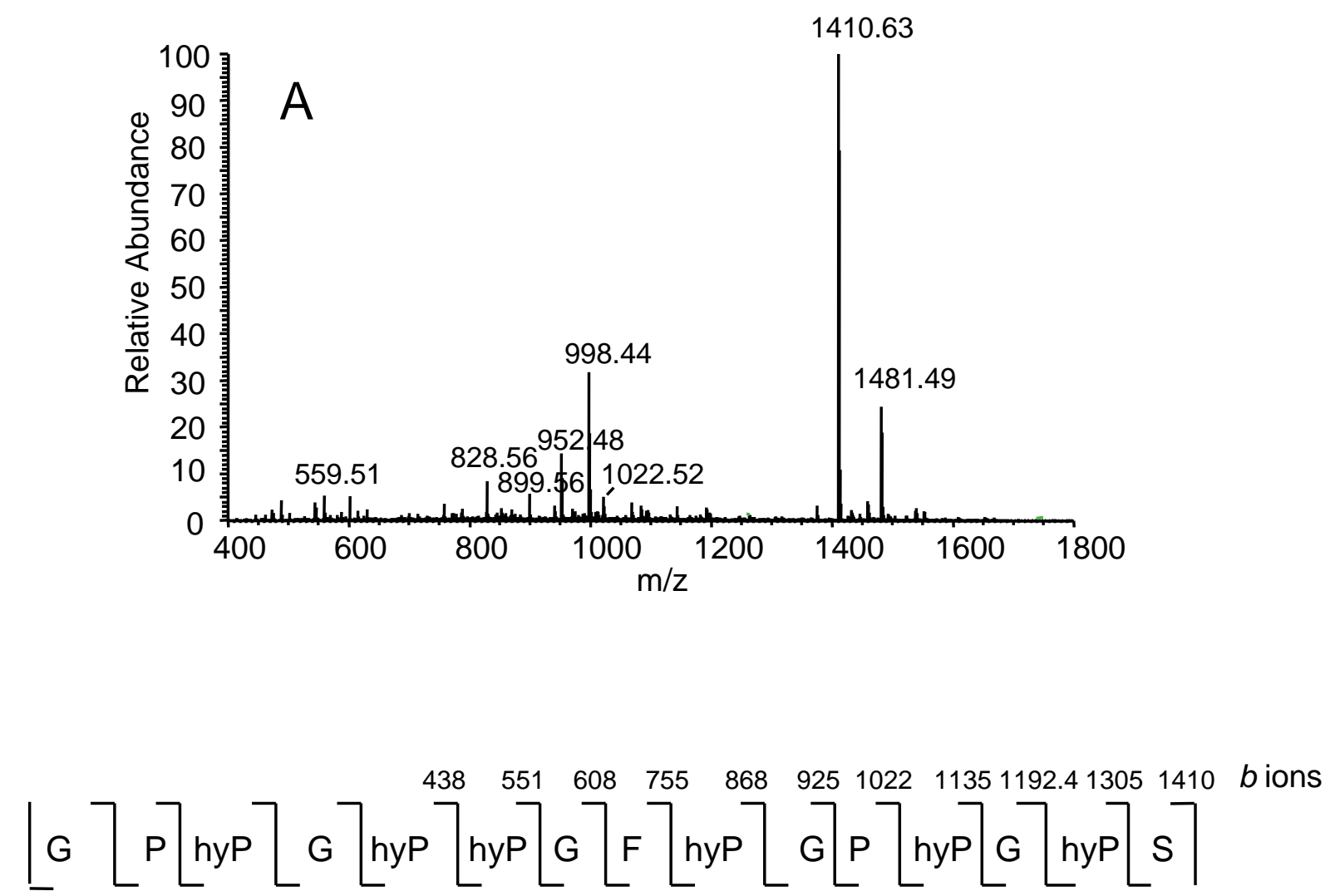
1410.61353 .51256 .51143 .461086 .4973 .4860 .4803 .4

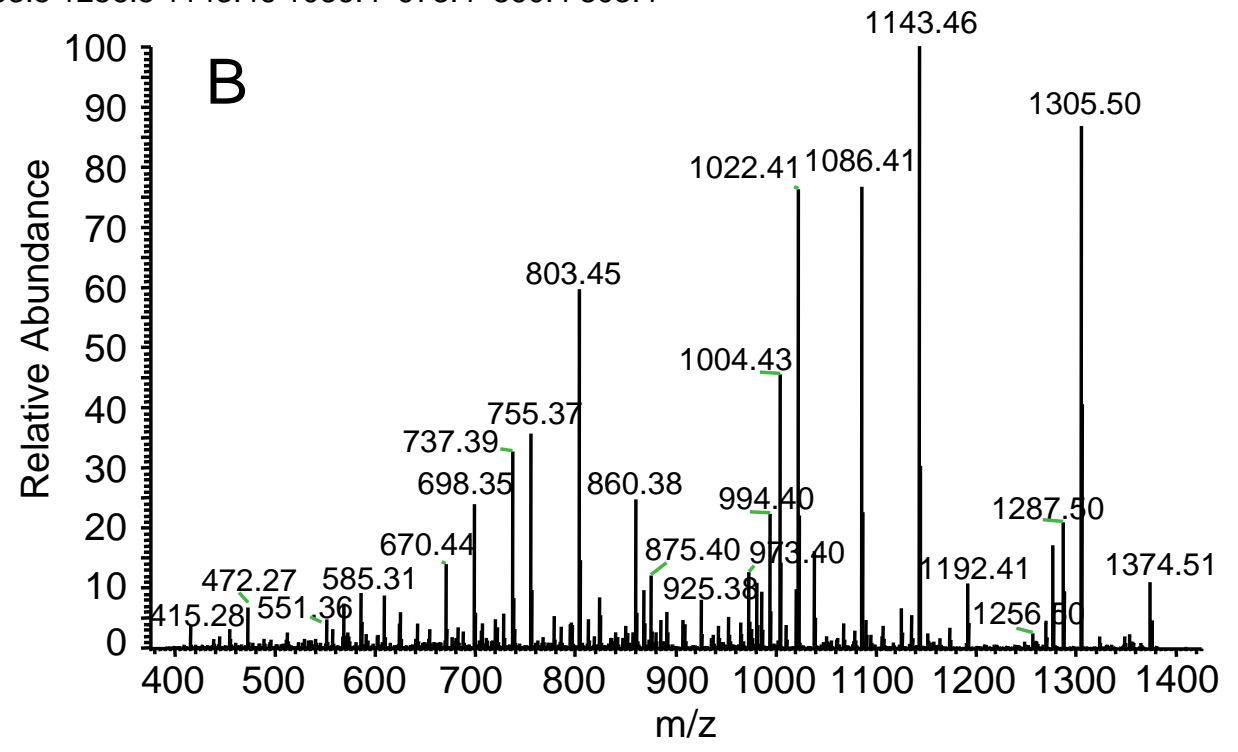

Figure 4 

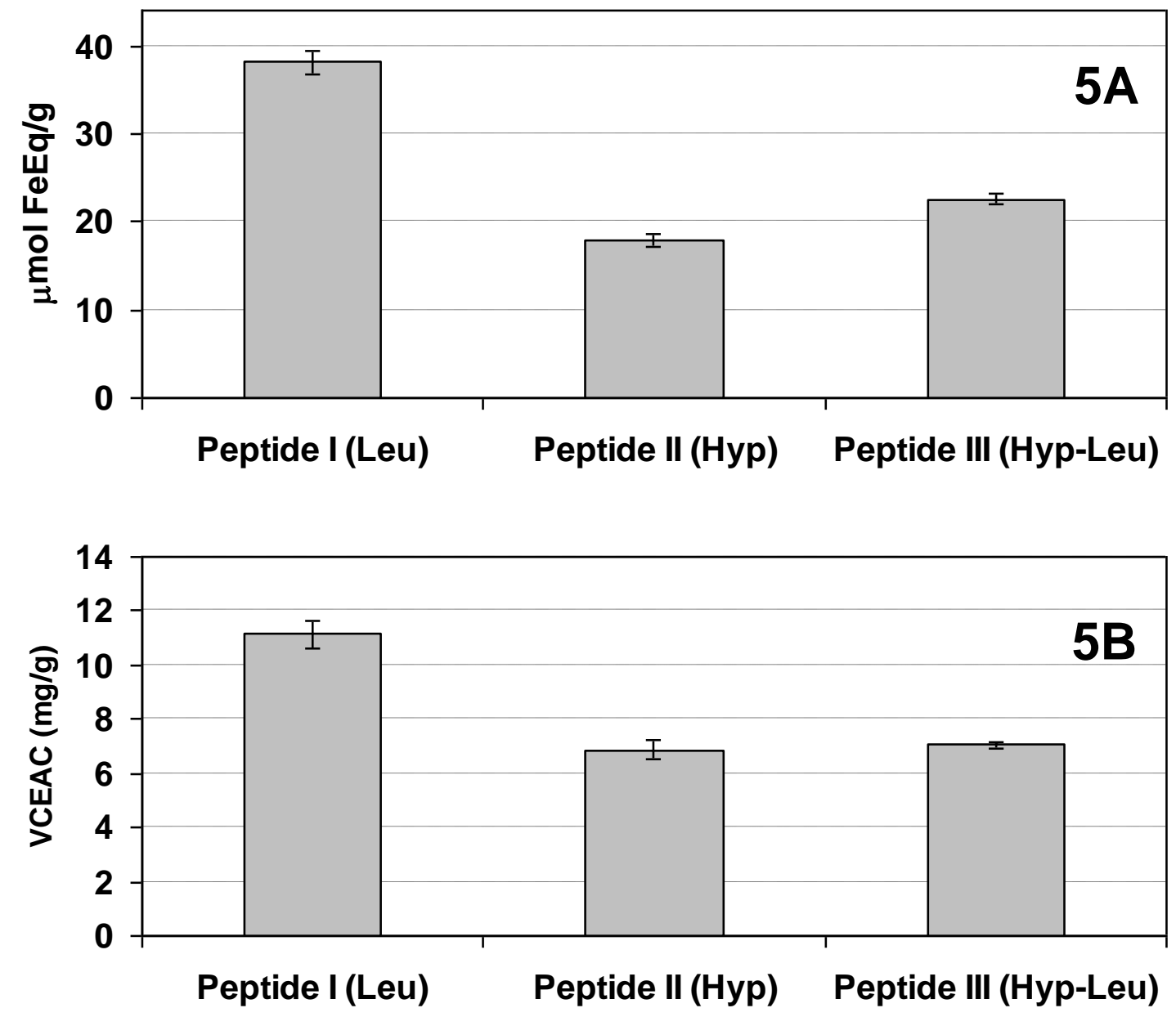

Fig. 5 
Table 1. Comparative amino acid profiles of fractionated UF-10

\begin{tabular}{ccccc} 
& \multicolumn{4}{c}{ Number of residues/1000 residues } \\
\hline Amino acid & F I & F II & F III & F IV \\
\hline Asp & 99 & 128 & 39 & 43 \\
Thr & 35 & 34 & 27 & 39 \\
Ser & 49 & 58 & 45 & 66 \\
Glu & 154 & 109 & 218 & 78 \\
Gly & 317 & 293 & 346 & 307 \\
Ala & 96 & 104 & 77 & 150 \\
Cys & 6 & 8 & 10 & 0 \\
Val & 21 & 19 & 22 & 29 \\
Met & 16 & 26 & 6 & 14 \\
Ile & 14 & 17 & 15 & 11 \\
Leu & 23 & 24 & 26 & 46 \\
Tyr & 3 & 5 & 8 & 10 \\
Phe & 10 & 11 & 9 & 18 \\
His & 1 & 1 & 0 & 0 \\
Lys & 1 & 2 & 3 & 1 \\
Arg & 5 & 4 & 6 & 7 \\
Pro & 70 & 76 & 59 & 93 \\
Hyp & 74 & 75 & 82 & 87 \\
Hyl & 5 & 8 & 1 & 0 \\
\hline
\end{tabular}


Table 2. ACE inhibitory capacity of synthetic peptides and Enalapril

\begin{tabular}{lc}
\cline { 2 - 2 } & IC $_{\mathbf{5 0}} \boldsymbol{\mu M}$ \\
\hline Peptide I & 90.03 \\
\hline Peptide II & non-detected \\
\hline Peptide III & 256.82 \\
\hline Enalapril & 7.34 \\
\hline
\end{tabular}

